\title{
CORPORATE GOVERNANCE AND FINANCING CHOICES IN FIRMS: A PANEL DATA ANALYSIS OF SRI LANKAN COMPANIES
}

\author{
Saseela Balagobei \\ Senior Lecturer, Department of Financial Management, \\ University of Jaffna, Sri Lanka. \\ E-mail: saseelab@univ.jfn.ac.lk
}

\begin{abstract}
An important financial decision facing firms is the choice between debt capital and equity capital. The financial structure of a firm is a specific mixture of debt and equity the firm uses to finance its operations. The financing choice of firms is crucial for any business organization. This paper investigated how corporate governance indicators such as board size, board independence, CEO duality and board meetings impact on financing choice of firms. Panel data covering a five year period from 2012 to 2016 from twenty six listed firms on the Colombo Stock Exchange (CSE) was used. Analysis was done within the Random-effects GLS regression framework. The findings reveal that organizations with larger board sizes employ more debt irrespective of the maturity period in order to raise corporate value. Further, other corporate governance variables such as board independence, CEO duality and board meetings are not found to have a significant impact on short term and long term leverage. The firms should increase their board size for accessing more debt capital as a large board size puts pressure on managers through stringent monitoring and regulatory mechanisms to increase the value of a firm. However beyond a certain level, further increase in board size could lead to adverse effects. Therefore, this study recommends a policy that may strike a good balance between quality and quantity of board size.
\end{abstract}

Keywords: board size, board independence, CEO duality, corporate governance, financing choice

\section{ARTICLE INFO}

Article History:

Received: 31 October 2019

Accepted: 27 February 2020

Published: 30 April 2020 


\section{INTRODUCTION}

Corporate Governance and financing choice plays a vital role in the maximization of shareholders' wealth. Good corporate governance is important in increasing the market value of a firm while higher financial leverage decreases a firm's value by increasing bankruptcy risks (Sheifer \& Vishny, 1997). Corporate governance has been mostly applicable in developed markets and essentially to large and listed firms. In recent times, however, the term is on the development agenda of many developing countries, the reason being the realization that corporate governance is important for the promotion of sustained growth as it boosts the bottom line (Kyereboah-coleman \& Biekpe, 2006). Corporate governance has two meanings. It refers to the relationship between a firm and its stakeholders including shareholders, employees, creditors, competitors, consumers etc. In the second definition, corporate governance is seen as signifying the mechanism for checking on and monitoring the behaviour of top management, due to the separation of ownership and control. Thus, corporate governance refers to the clear establishment of how an organization ought to be run and controlled and ensure accountability on the part of management towards owners. Studies have shown that corporate governance enhances performance (Gompers et al., 2003; Claessens et al., 2002).

An important financing decision facing firms is the choice between debt and equity capital (Glen \& Pinto, 1994). The capital structure of a firm is a mix of debt and equity the firm uses to finance its operations. The decision is important because of the need to maximise returns to various organisational constituencies and also because of the impact such a decision has on an organisation's ability to deal with its competitive environment (Abor \& Biekpe, 2005). The task of the firm is to choose a portfolio of capital structure that will maintain sustainability and generate more wealth. In general, a firm can choose among many alternative capital structures. It can issue a large amount of debt or very little debt. It can arrange lease financing, use warrants, issue convertible bonds, sign forward contracts or trade bond swaps. In an attempt to set a capital structure that maximises overall market value, firms differ in the way they deal with the issue of optimising capital structure requirements. Corporate governance refers to how companies ought to be run, directed and controlled. It is about supervising and holding to account those who direct and control the management. It is believed that, 
good governance generates investor goodwill and confidence. Gompers et al. (2003) assert that, good corporate governance increases valuations and boosts the bottom line. Claessens et al. (2002) also maintain that better corporate frameworks benefit firms through greater access to financing, lower cost of capital, better performance and more favourable treatment of all stakeholders.

Corporate governance has been identified in previous studies to influence firms' financing or capital structure decisions which also affect performance (Berger et al., 1997; Friend \& Lang, 1988). These empirical studies tended to focus mainly on developed economies with inconclusive results. Very little, however, has been done on corporate governance in Sri Lanka, especially with respect to firms' financing decisions. It is crucial to determine how current issues in corporate governance affect the financing choice of Sri Lankan firms. This study specifically examined the impact of various variables of corporate governance on the financing choice of manufacturing companies in the Sri Lanka during a five-year period (2012-2016). The findings of the study have key implications for policymakers, practitioners, investors and regulatory authorities. It contributes to the Agency Theory-debt and equity capital discourse in the context of an emerging country where corporate governance systems appear weak.

\section{Research Problem}

With a sound governance structure (CG), it is much easier for organizations to obtain loans from investors as a functional corporate structure protects the interest of shareholders, increases transparency and reduces agency conflicts. Firms with poor governance practices face more agency problems as managers of such firms can easily obtain private benefits due to a poor CG structure.

Weak corporate governance does not only lead to poor firm performance and risky financing patterns, but is also conducive for macroeconomic crises (Claessens et al., 2002). Becht et al. (2002) identify a number of reasons for the growing importance of corporate governance; including, the world-wide wave of privatization of the past two decades, the pension fund reform and the growth of private savings, the takeover wave of the 1980s, the deregulation and integration of capital markets, the 1997 
East Asia Crisis, and the series of recent corporate scandals in the USA and elsewhere. Developing countries are now increasingly embracing the concept of good corporate governance, because of their ability to impact positively on sustainable growth. The dominance of large shareholders may therefore affect the financing choice of firms. Businesses are therefore, being compelled to apply the most scientific methods to enable them compete in the global market. The will of investors to strive for excellence and the refusal to accept mediocrity have created stiff competition in the business environment. This drive for excellence and competition has led to the demand for information by stakeholders. Corporate bodies are continually being compelled to disclose relevant information to stakeholders and the communities in which they operate. They are required to be more transparent in their dealings and to justify their investments and financing choice. A study of the characteristics of corporate governance and the financing choice of Sri Lankan listed firms is therefore very crucial. This study provides empirical evidence on corporate governance and firms' financing choice from the context of a developing economy. Therefore this study addressed the research question "To what extent does corporate governance impact on financing choice. The objective was to examine the impact of corporate governance on financing choice of Sri Lankan listed manufacturing firms.

This paper is organized as follows: the next section provides an overview of the empirical literature on the subject matter. The following section describes the research methodology. The penultimate section discusses the results of the analysis. Finally, the last section summarizes the results and concludes the discussion.

\section{LITERATURE REVIEW}

\section{Theoretical Literature}

Corporate governance has been given various definitions by various authors. Metrick and Ishii (2002) define corporate governance from the perspective of the investor as "both the promise to repay a fair return on capital invested and the commitment to operate a firm efficiently given (that) investment". This definition simply suggests that the nature of the governance structure of a firm has an impact on its ability to access capital markets. 
The theoretical framework upon which corporate governance and capital structure is based includes the Agency Theory and the Free Cash Flow Theory. Evidence from previous empirical studies has sought to confirm the effect of CG on firm performance and reviewed the theories.

Agency Theory: CG has traditionally been associated with the "principal-agent" or "agency" paradox. A "principal-agent" relationship arises when the person who owns a firm is not the same as the person who managers or controls it. The Agency Theory has its roots in economic theory and was developed by Jensen and Meckling (1976) and it states that shareholders who are the owners or principals of the company delegate the running of a business to managers or agents. The shareholders expect the agents to act and make decisions in the principal's interest but the agents may make contrary decisions. Jensen and Meckling (1976) argued that the separation of ownership and control has resulted in an agency problem as the managers who act as agents might not always act in the best interests of the shareholders or owners, who are the principals of the firm. This might be due to the interests of both parties which are not aligned. The agency problem results in agency costs, which are the costs of the separation of ownership and control. Agency costs have been defined as the sum of the monitoring expenditures by the principal, the bonding expenditures by the agent and the residual costs.

Free Cash Flow Theory: According to the Free Cash Flow Theory (Jensen, 1986), leverage itself can also act as a monitoring mechanism and thereby reduces the agency problem hence increasing firm value by reducing the agency costs of free cash flow. There are some consequences derived if a firm is employing a higher leverage level in that managers of such firms will not be able to invest in non-profitable new projects, as by doing so the new projects might not be able to generate cash flow to the firm, hence managers might fail in paying the fixed amount of interest on the debt or the principal when it is due. It also might cause the inability to generate profit in a certain financial year that may result in failing to pay dividends to firm shareholders. Leverage might not only be able to reduce agency costs of free cash flow, but also can increase the efficiency of managers. This is due to the debt market that might function as a more effective capital market monitoring. In addition, in order to obtain debt financing, managers must show their abilities and efficiencies in managing a firm. Empirically, it 
has been proven that leverage proxied by bank lenders, can be a substitute monitoring mechanism especially in weak CG firms, but not in the more active merger environments.

\section{Empirical Literature}

There have been some studies that link corporate governance and financing choice of firms. For instance, Berger et al. (1997), Friend and Lang (1988), Wen et al. (2002), and Abor (2007), show that the nature of corporate governance in a firm has an influence on its financing decisions. The main corporate governance characteristics that have been identified to impact on financing decisions of firms include board size, board composition, CEO duality, tenure of the CEO, and the CEO's compensation. The empirical literature on governance and capital structure so far, though scanty, shows varied results and appear largely inconclusive.

Musa, Musová, and Debnárová (2015) found that the application of the principles of corporate governance affects financial decisions of companies. There is a correlation between the responsible application of corporate governance principles and the total debt of companies and also, there is a correlation between responsible application of corporate governance principles and the amount of dividends paid to shareholders. Further Kieschnick and Moussawi (2018) showed that the effects of firm age on how much debt a firm uses is primarily due to the interaction between firm age and its governance features. Then, managers allow their risk preferences to dominate their firm capital structure decisions when they are protected from discipline. Sheikh (2019) shows that corporate governance mechanisms have some role in shaping the financing behavior of firms. It is worth mentioning that each company is bound to explicitly confirm in the annual report regarding compliance with the code of corporate governance.

Changa, Choub, and Huanga (2014) proved that both over levered and under levered firms with weak governance adjust slowly toward their target debt levels, though with different motivations. Chow et al. (2018) point out that overall effect of macroeconomic uncertainty on capital structure among firms with better governance quality is significantly negative. Corporate governance acts as an effective mechanism to curb the usage of leverage during times of high volatility. Further analysis shows that board 
independence, the separation between the roles of CEO and chairman of the board and block holders' ownership are effective governance mechanisms, whereas similar observations do not hold for board size and institutional ownership.

Boateng et al. (2017) found that independent directors and ownership concentration exert a significant influence on the level of Chinese long-term debt after controlling firm-specific determinants and split share reforms. Bokpin and Arko (2009) reveal that managerial shareholding significantly positively influences the choice of long-term debt over equity. Among the corporate governance variables, board size was found to be positively and statistically significantly related to capital structure choices.

The board of any corporate entity is the highest decision making body entrusted with the responsibility of ensuring that the firm operates efficiently and competitively. The board size measured by the number of people that constitute it has a significant relationship with the financing decision of a firm according to Pfeffer and Selancick (1978), and Lipton and Lorsch (1992). Berger et al. (1997) show that firms with larger board sizes tend to have low leverage or concentrate rather on equity financing. The underlying principle is that a large board size inevitably translates into coercion from the board on managers to rather depend on less debt to enhance firm performance. A critical issue raised by Jensen (1986), however, is that firms with a high leverage or a high debt ratio have larger boards. This twist introduces the issue of causality. The question is, do firms resort to high leverage because they have larger board sizes or do firms increase board sizes because they are highly leveraged? Studies on this issue are largely non-existent. However, empirical results in China by Wen et al. (2002) and by Abor in Ghana (2007) point to a positive relationship between board size and leverage. These findings presuppose that large board sizes that exist largely due to monitoring by regulatory bodies, target higher leverage to enhance corporate value. It could also be due to the difficulty of arriving at consensus in decision-making. Such a scenario has the tendency of weakening corporate governance leading to dependence on high leverage primarily as a disciplining mechanism for firm value maximization. Furthermore, Anderson et al. (2004) point out that the cost of debt is lower for larger boards probably due to the fact that creditors view these firms as essentially having effective monitoring on their operations. 
Studies have also shown that the nature of board structure typology (CEO duality) also has a relationship with the financing decisions of a firm. In this case, studies have centered on 1-tier and 2-tier board structure typologies. A firm is said to have a 1-tier board structure if the CEO combines as the board chairperson. On the other hand, in a situation where the CEO and board chair positions are occupied by separate personalities, the firm is said to be operating a 2-tier board structure. In the one-tier board structure typology, it is deemed that the two critical issues of decision making and control are vested in the same personality, which is however thought to be inappropriate (Fama \& Jensen, 1983). Again, Fama and Jensen (1983) define "decision management" as the right vested in a CEO to initiate and implement new proposals warranting expenditure of the firm's resources, while "decision control" is the right to ratify and monitor these proposals. Hence, there exists a conflict of interest and higher agency costs if these are done by the same personality signaling the lack of separation of "decision management and decision control". Fosberg (2004) shows that a 2-tier board structure typology is characterized by higher leverage or debt: equity ratios as compared to a 1-tier leadership scenario. Abor (2007) in a Ghanaian study however found a negative relationship between a 2-tier board structure typology and leverage.

The other related characteristic of corporate governance is compensation of the CEO. CEOs with attractive fixed compensation might pursue lower leverage to reduce the financial risk and keep their job for the attractive remuneration (Stulz, 1988; Harris \& Raviv, 1988). However, empirical evidence has shown contradictory findings. Jensen and Meckling (1976), and Berger et al. (1997) show a positive association between CEO compensation and capital structure of the firm. Wen et al. (2002), Friend and Hasbrouck (1988) also find a negative relationship between fixed compensation and financial leverage.

Based on the literature review, the following hypotheses were developed,

$\mathbf{H}_{1}$ : Board size has a significant impact on financing choice.

$\mathbf{H}_{2}$ : Board independence has a significant impact on financing choice.

$\mathbf{H}_{3}$ : CEO duality has a significant impact on financing choice.

$\mathbf{H}_{4}$ : Board meeting has a significant impact on financing choice. 


\section{METHODOLOGY}

\section{Data and Variable Description}

Data for the study was obtained from twenty six (26) manufacturing companies listed on the Colombo Stock Exchange (CSE) covering a five (5) year period from 2012-2016. For the dependent variable, the firm's debt ratio was measured as the ratio of total debt to total assets (i.e. LEV $=$ Leverage). For a deeper understanding of further relationships, leverage was divided into short-term leverage (STL) and long-term leverage (LTL) which are measured as the ratio of short-term debts and long-term debts to total assets respectively. Regarding the independent variables, board size (BDS) measured by the number of board members, board independence (BDI) measured by the ratio of independent board members to board size, CEO duality (CEO) which is a dummy and is equal to unity when a CEO doubles as board chairperson and zero otherwise and board meeting measured by number of meetings held per year.

\section{Research Model}

The study followed the panel model specification for the purpose of estimating the impact of corporate governance on financing choice of listed manufacturing companies in Sri Lanka. The panel data model is as follows:

$$
\mathrm{Yit}=\alpha \mathrm{i}+\beta 1 \mathrm{X} 1 \text { it }+\beta 2 \mathrm{X} 2 \text { it }+\beta 3 \mathrm{X} 3 \text { it }+\beta 4 \mathrm{X} 4 \text { it }+\varepsilon \text { it }
$$

Where Yit is leverage of firm $i$ at time $t, \alpha i$ is a constant term, $\beta 1, \beta 2$, $\beta 3$ and $\beta 4$ are the beta coefficients, $X 1, X 2, X 3$ and $X 4$ are the explanatory variables used in the study, and $E$ it is the error term. The specific models are as follows:

$$
\begin{aligned}
& \mathrm{STL} \text { it }=\alpha \mathrm{i}+\beta 1 \mathrm{BS}+\beta 2 \mathrm{BI}+\beta 3 \mathrm{CEO}+\beta 4 \mathrm{BM}+\mathrm{Eit} \\
& \mathrm{LTL} \text { it }=\alpha \mathrm{i}+\beta 1 \mathrm{BS}+\beta 2 \mathrm{BI}+\beta 3 \mathrm{CEO}+\beta 4 \mathrm{BM}+\varepsilon \mathrm{it} \\
& \mathrm{LEVit}=\alpha \mathrm{i}+\beta 1 \mathrm{BS}+\beta 2 \mathrm{BI}+\beta 3 \mathrm{CEO}+\beta 4 \mathrm{BM}+\mathrm{Eit}
\end{aligned}
$$


Where,

$\begin{array}{lll}\text { STL it } & - & \text { Short-term leverage of firm i at time } t . \\ \text { LTL it } & - & \text { Long-term leverage of firm i at time } t . \\ \text { LEVit } & - & \text { Total leverage of firm } i \text { at time } t . \\ \text { BS it } & - & \text { Board size of firm } i \text { at time } t . \\ \text { BIit } & - & \text { Board independence of firm } i \text { at time } t . \\ \text { CEOit } & - & \text { CEO duality of firm } i \text { at time } t . \\ \text { BM it } & - & \text { Board meeting of firm } i \text { at time } t .\end{array}$

\section{Choosing Between Random and Fixed Effects}

The most basic estimator of panel data sets is the pooled Ordinary Least Squares (OLS). In the simplest case in which there are no firm specific and time specific effects the ordinary least square is the most appropriate. Johnston and Dinardo (1997) recall that the pooled OLS estimators ignore the panel structure of the data, treating observations as being serially uncorrelated for a given firm with homoscedastic errors across individuals and time periods. A more appropriate approach is therefore to estimate the model using other panel data techniques.

Hausman (1978) suggested a test to check whether the individual effects are correlated with the regressors. Under the null hypothesis no correlation between individual effects and explanatory variables. Under the alternative hypothesis individual effects are correlated with the regressors, the random effects estimator is inconsistent while the fixed effects estimator is consistent and efficient. The following hypotheses were tested applying the Hausman test.

$\mathbf{H}_{\mathbf{0}}$ : There is no significant difference between co-efficient estimates.

$\mathbf{H}_{\mathbf{1}}$ : There is a significant difference between co-efficient estimates.

If the chi.sq value is significant, $\mathrm{H} 1$ will be supported. It implies that there is a significant difference between co-efficient estimates. Hence, this will lead to the rejection of random effects estimator. 


\section{DISCUSSION AND FINDINGS}

\section{Descriptive Analysis}

Table 1 shows the summary statistics of both dependent and independent variables.

Table 1: Descriptive Statistics

\begin{tabular}{lccccccc}
\hline & BS & BI & $\begin{array}{c}\text { CEO } \\
\text { Duality }\end{array}$ & BM & STL & LTL & LEV \\
\hline Mean & 7.692 & 0.379 & 0.061 & 3.984 & 0.728 & 0.271 & 0.383 \\
Median & 8.000 & 0.333 & 0.000 & 4.000 & 0.807 & 0.193 & 0.384 \\
Maximum & 12.000 & 0.667 & 1.000 & 8.000 & 1.196 & 2.920 & 0.815 \\
Minimum & 3.000 & 0.125 & 0.000 & 0.000 & -1.920 & -0.196 & -0.224 \\
Std. Dev. & 1.928 & 0.127 & 0.241 & 1.317 & 0.317 & 0.317 & 0.174 \\
Skewness & -0.320 & 0.345 & 3.649 & -0.767 & -5.025 & 5.025 & 0.004 \\
Kurtosis & 2.853 & 2.423 & 14.315 & 5.675 & 39.655 & 39.655 & 3.381 \\
\hline & & & & & & & \\
Jarque-Bera & 2.343 & 4.396 & 982.066 & 51.528 & 7825.251 & 7825.251 & 0.789 \\
Probability & 0.309 & 0.111 & 0.000 & 0.000 & 0.000 & 0.000 & 0.673 \\
& & & & & & & \\
\hline Sum & 1000 & 49.395 & 8.000 & 518.000 & 94.692 & 35.308 & 49.851 \\
Sum Sq. Dev. & 479.692 & 2.090 & 7.507 & 223.969 & 12.996 & 12.996 & 3.936 \\
Observations & 130 & 130 & 130 & 130 & 130 & 130 & 130 \\
\hline
\end{tabular}

(STL - Short-term leverage, LTL - Long-term leverage, LEV - Total leverage, BS - Board size, BI - Board independence, CEO - CEO duality, BM - Board meeting)

According to Table 1 the mean board size is about eight with the minimum and maximum being three and twelve respectively. The standard deviation for board size is 1.928 . With board independence, the mean ratio of $37.9 \%$ suggests that more insiders serve on these boards as against outsiders. This also suggests that these boards are relatively less independent (John \& Senbet, 1998). However, the minimum and maximum of $12.5 \%$ and 66.7 $\%$ is an indication that some of the boards are largely independent. On the average, $6.1 \%$ of the boards operate a 2-tier board structure meaning that firms have the critical roles of decision-taking and decision-management embedded in two personalities. The standard deviation for CEO duality is 0.241. Most of the firms depend on short-term debt as against long-term debt. The mean of short-term leverage is $72.8 \%$ with the standard deviation of 0.317 . 


\section{Regression Analysis}

Table 2 represents the results of multiple regression analysis to examine the impact of corporate governance on financing choices of listed manufacturing companies in Sri Lanka.

Table 2: Regression for Corporate Governance and Financing Choices of Firms

\begin{tabular}{lccc}
\hline \multicolumn{1}{c}{ Variables } & $\begin{array}{c}\text { Short-term } \\
\text { leverage } \\
\text { (Random Effect } \\
\text { Estimation) }\end{array}$ & $\begin{array}{c}\text { Long-term } \\
\text { leverage } \\
\text { (Random } \\
\text { Effect } \\
\text { Estimation) }\end{array}$ & $\begin{array}{c}\text { Leverage (Total) } \\
\text { (Random Effect } \\
\text { Estimation) }\end{array}$ \\
\hline Constant & 0.641337 & 0.358663 & 0.214175 \\
Board size & $(0.0003)$ & $(0.0379)$ & $(0.0263)$ \\
Board independence & $0.075018^{* *}$ & $0.073444^{* *}$ & $0.037437^{* *}$ \\
CEO Duality & $(0.0023)$ & $(0.019)$ & $(0.0061)$ \\
Board meetings & -0.051394 & -0.080593 & 0.018584 \\
& $(0.8221)$ & $(0.1893)$ & $(0.884)$ \\
R-squared & 0.03297 & -0.045729 & 0.068645 \\
No of observation & $(0.7802)$ & $(0.2383)$ & $(0.2983)$ \\
Hausman test -Chi-Sq & -0.025267 & -0.025584 & 0.00115 \\
Prob(F-statistic) & $(0.119)$ & $(0.8582)$ & $(0.8982)$ \\
\hline Notic & 0.1349 & 0.0777 & 0.1127 \\
& 130 & 130 & 130 \\
& 2.360245 & 7.34997 & $4(0.8274)$ \\
& 0.021431 & 0.03236 & 0.042542 \\
\hline
\end{tabular}

Notes: All regressions include a constant. Probability values in brackets. ${ }^{* *}$ indicate significance at the 5 per cent level.

In Table 2, the results of the Hausman specification test do not allow to reject the null hypothesis that the difference in coefficients is not systematic. Given such results, the preferred model is the Random-effects GLS because it is consistent and efficient under the circumstances. 
The study shows that short-term leverage, long term leverage and total leverage have a significant positive correlation with board size, thus contradicting the findings of Berger et al. (1997) who showed that firms with large board sizes employ less leverage. The positive relationship between board size and leverage suggests that larger boards employ a high debt policy to raise corporate value. This may be due to an apparent lack of consensus building due to board size resulting in weaker corporate governance. This finding is consistent with other studies (Jensen, 1986; Wen et al., 2002; Abor, 2007). Again, this could be due to the fact that large board sizes, which are relatively more entrenched due to monitoring by regulatory bodies, make it a deliberate policy to target higher leverage for the purpose of enhancing corporate value. Therefore, as board size has a significant impact on financing choice such as short-term leverage $\left(\beta=0.075018^{* *}\right.$, $\mathrm{P}<0.05)$, long term leverage $\left(\beta=0.073444^{* *}, \mathrm{P}<0.05\right)$ and liability $(\beta=0$. $\left.0.037437^{* *}, \mathrm{P}<0.05\right)$, hypothesis one (H1) is supported.

The results show that board independence is insignificant in explaining short-term leverage, long-term leverage and total leverage. So, H2 is not supported. Further, CEO duality and board meetings have an insignificant impact on short-term leverage, long-term leverage and total leverage $(\mathrm{P}>0.05)$. Therefore, $\mathrm{H} 3$, and $\mathrm{H} 4$ are not supported. The F-statistics values are $2.360245(\mathrm{P}<0.05)$ for short-term leverage, $1.346875(\mathrm{P}<0.05)$ for long-term leverage and $1.922302(\mathrm{P}<0.05)$ for total leverage which show that the corporate governance variables jointly significantly explain the variations in short-term leverage, long-term leverage and total leverage. The R-square value of $0.1349,0.0777$ and 0.1127 represent that variation of $13.49 \%, 7.77 \%$, and $11.27 \%$ in short-term leverage, long-term leverage and total leverage are explained by corporate governance variables respectively.

\section{CONCLUSION}

The objective of this research was to examine the impact of corporate governance on financing choice of listed manufacturing companies in Sri Lanka. Corporate governance refers to how corporate entities ought to be run, directed and controlled. It is indeed believed that better corporate governance enhances a firm's profile through better access to finance, lower cost of capital, better performance and preferential treatment on the 
part of all stakeholders. Of critical importance is the fact that the concept of corporate governance is now dominating the policy agenda of most developing nations.

This study looked at corporate governance and its impact with financing choice of listed manufacturing firms by using data from 26 listed firms on the Colombo stock exchange covering the period 2012 to 2016. The random-effects GLS panel data regression model was employed and results show that board size significantly influences on financing choice of firms and other corporate governance variables do not have any impact on financing choice such as short-term leverage, long-term leverage and total leverage. In conclusion therefore, it is recommended that firms position themselves by strengthening governance structures in order to promote their attractiveness and therefore their capacity to access financial markets. The findings of this study may be useful to policy makers to formulate appropriate policies of corporate governance. These findings could help to reinforce the importance of good governance among policy makers of a country as well as managers of firms.

\section{REFERENCES}

Abor, J. (2007). Corporate governance and financing decisions of Ghanaian listed firms. Corporate Governance, 7(1), 83-92.

Abor, J., \& Biekpe, N. (2005). What determines the capital structure of listed firms in Ghana?. African Finance Journal, 7(1), 37-48.

Anderson, R., Mansi, S. \& Reeb, D. (2004). Board characteristics, accounting report integrity and the cost of debt. Journal of Accounting and Economics, 37, 315-342.

Becht, M., Bolton, P., \& Rosell, A. (2002). Corporate governance and control (NBER Working Paper Number 9371). Retrieved from National Bureau of Economic Research website: http://www.nber.org/papers/ w9371.pdf

Berger, P. G., Ofek, E., \& Yermack, D. L. (1997). Managerial entrenchment and capital structure decisions. Journal of Finance, 52(4), 1411-1438. 
Boateng, A., Cai, H., Borgia, D., Gang Bi, X., \& Ngwu, F. (2017). The influence of internal corporate governance mechanisms on capital structure decisions of Chinese listed firms. Review of Accounting and Finance, 16(4), 444-461.

Bokpin, G., \& Arko, A. (2009). Ownership structure, corporate governance and capital structure decisions of firms: Empirical evidence from Ghana. Studies in Economics and Finance, 26(4), 246-256.

Changa, J., Choub, R., \& Huanga, T. (2014). Corporate governance and the dynamics of capital structure: New evidence. Journal of Banking and Finance, 48, 374-385.

Chow, Y., Muhammad, J., Bany-Ariffin, A., \& Cheng, F. (2018). Macroeconomic uncertainty, corporate governance and corporate capital structure. International Journal of Managerial Finance, 14(3), 301-321.

Claessens, S., Djankov, S., Fan, J. P., \& Lang, L. H. (2002). Disentangling the incentive and entrenchment effects of large shareholdings. The Journal of Finance, 57(6), 2741-2771.

Fama, E., \& Jensen, M. (1983). Separation of ownership and control. Journal of Law and Economics, 26(2), 301-325.

Fosberg, R. H. (2004). Agency problems and debt financing: Leadership structure effects. Corporate Governance, 4(1), 31-38.

Friend, I., \& Hasbrouk, J. (1988). Determinants of capital structure. Research in Finance, 7(1), 1-19.

Friend, I., \& Lang, L. H. (1988). An empirical test of the impact of managerial self-interest on corporate capital structure. The Journal of Finance, 43(2), 271-281.

Glenn, J., \& Pinto, B. (1994). Debt or equity? How firms in developing countries choose (Discussion Paper 22). International Finance Corporation. 
Gompers, P., Ishii, J., \& Metrick, A. (2003). Corporate governance and equity prices. The Quarterly Journal of Economics, 118(1), 107-156.

Harris, M., \& Raviv, A. (1990). Capital structure and the informational role of debt. Journal of Finance, 45, 321-345.

Hausman, J. (1978). Specification tests in econometrics. Econometrica, $46,1251-1271$.

Jensen, M. C., \& Meckling, W. H. (1976). Theory of the firm: Managerial behaviour, agency costs, and ownership structure. Journal of Financial Economics, 3, 305-350.

Jensen, M. C. (1986). Agency costs of free cash flow, corporate finance, and takeovers, American Economic Review, 76, 323-329.

John, K., \& Senbet, L. W. (1998). Corporate governance and board effectiveness. Journal of Banking and Finance, 22, 371-403.

Johnston, J., \& Dinardo, J. (1997). Econometric methods (4 ${ }^{\text {th }}$ ed.). NY: McGraw Hill.

Kieschnick, R., \& Moussawi, R. (2018). Firm age, corporate governance, and capital structure choices. Journal of Corporate Finance, 48, 597-614.

Kyereboah-coleman, A., \& Biekpe, N. (2006). Corporate governance and financing choices of firms: A panel data analysis. South African Journal of Economics, 74(4), 670-681.

Lang, L. (1988). An empirical test of the impact of managerial self-interest on corporate capital structure. Journal of Finance, 47, 271-281.

Lipton, M., \& Lorsch, J. W. (1992). A modest proposal for improved corporate governance. Business Lawyer, 48, 59-77.

Metrick, A., \& Ishii, J. (2002, April). Firm-level corporate governance. In Global Corporate Governance Forum Research Network Meeting, Washington, DC April. 
Musa, H., Musová, Z., \& Debnárová, L. (2015). Responsibility in the corporate governance framework and financial decision making process. Procedia Economics and Finance, 23, 1023-1029.

Pfeffer, J., \& Salanick, G. R. (1978). The external of organizations: A resource-dependence perspective. New York: Harper \& Row.

Sheikh, N. (2019). Corporate governance and capital structure: Evidence from Pakistan. Research in Corporate and Shari'ah Governance in the Muslim World: Theory and Practice, 341-353.

Shleifer, A., \& Vishny, R. W. (1997). A survey of corporate governance. The Journal of Finance, 52, 737-783.

Stulz, R. (1990). Managerial discretion and optimal financing policies. Journal of Financial Economics, 26, 3-27.

Verbeek, M. (2004). A guide to modern econometrics (2 $2^{\text {nd }}$ ed.). West Sussex, UK: John Wiley \& Sons.

Wen, Y., Rwegasira, K., \& Bilderbeek, J. (2002). Corporate governance and capital structure decisions of the Chinese listed firms. Corporate Governance: An International Review, 10(2), 75-83. 